NUREG-0750

Vol. 45

Index 1

\title{
INDEXES TO \\ NUCLEAR REGULATORY COMMISSION ISSUANCES
}

\section{January - March 1997}

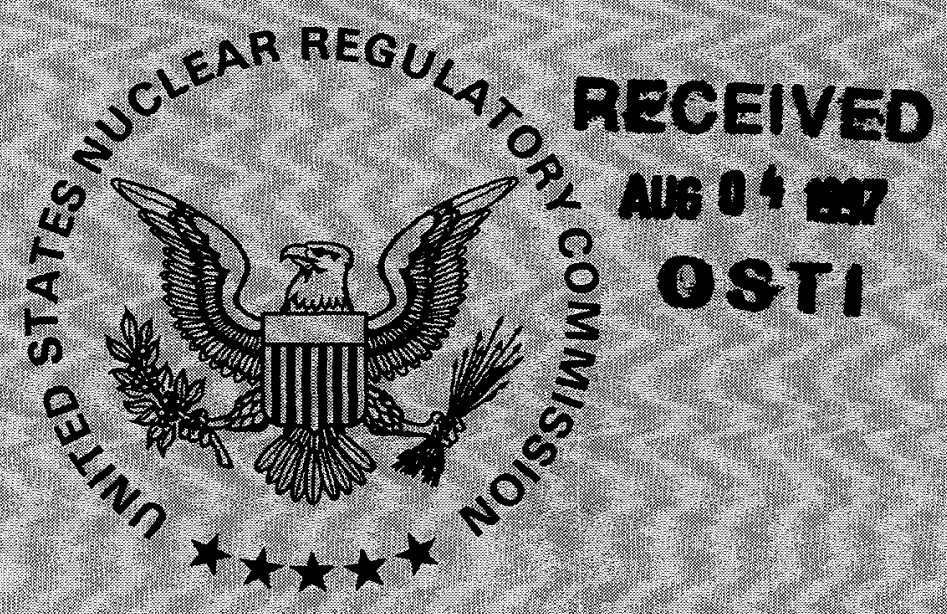

U.S. NUCLEAR REGULATORY COMMISSION

ESTRIBUTION OF THIS DOCUMENT IS UNLIMITED 
Available from

\section{Superintendent of Documents U.S. Government Printing Office P.O. Box 37082 \\ Washington, DC 20402-9328}

A year's subscription consists of 12 softbound issues, 4 indexes, and 2-4 hardbound editions for this publication.

Single copies of this publication are available from

National Technical Information Service

Springfield, VA 22161

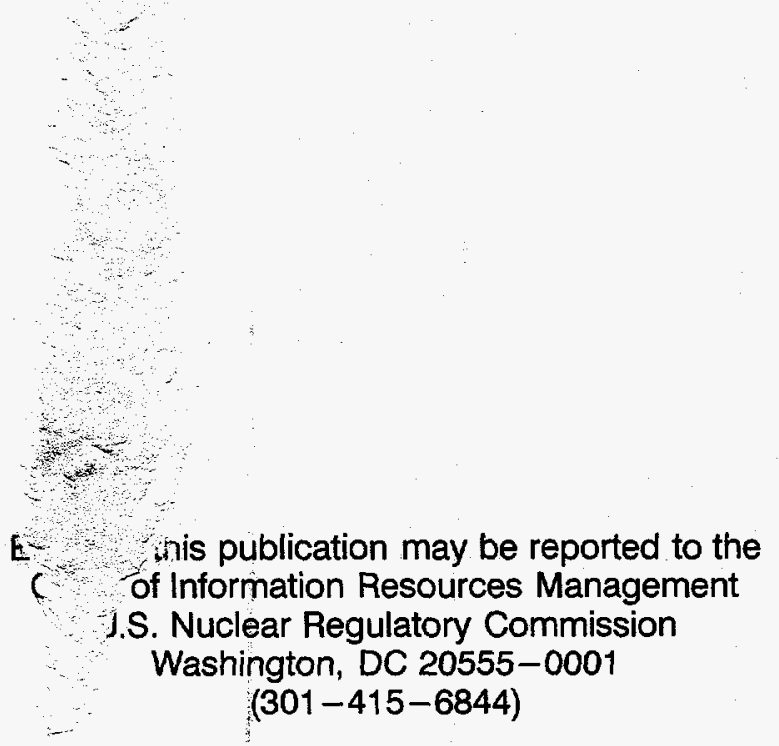




\section{INDEXES TO \\ NUCLEAR REGULATORY COMMISSION ISSUANCES}

January - March 1997

U.S. NUCLEAR REGULATORY COMMISSION

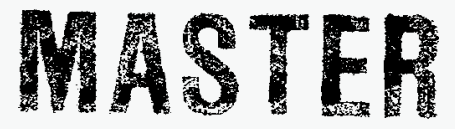

Prepared by the

Office of Information Resources Management

U.S. Nuclear Regulatory Commission

Washington, DC 20555-0001

(301-415-6844)

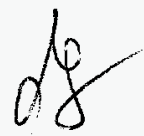

DSTRIBUTION OF THIS DOCUMENT IS UNLIMITED 


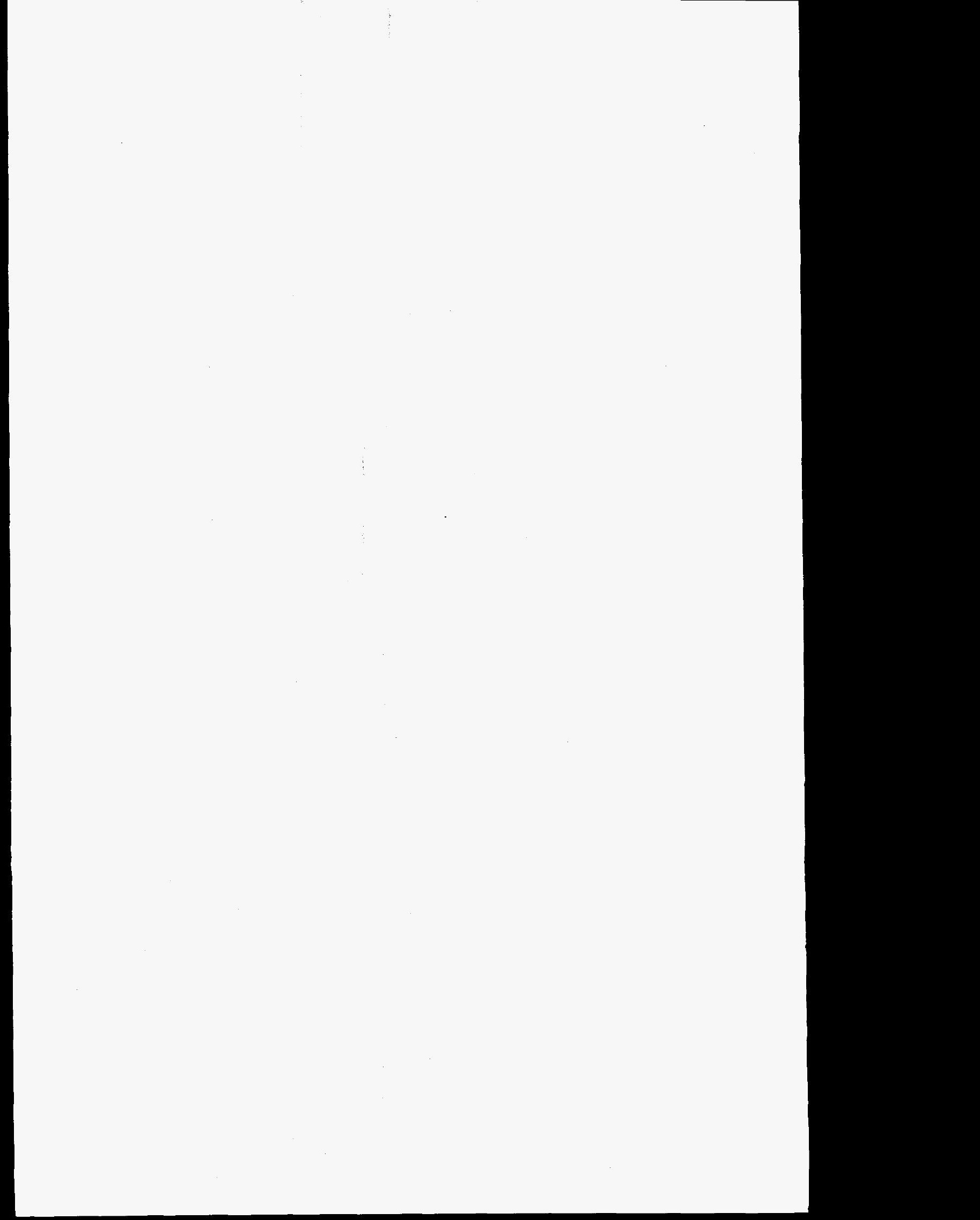




\section{Foreword}

Digests and indexes for issuances of the Commission (CLI), the Atomic Safety and Licensing Board Panel (LBP), the Administrative Law Judges (ALJ), the Directors' Decisions (DD), and the Decisions on Petitions for Rulemaking (DPRM) are presented in this document. These digests and indexes are intended to serve as a guide to the issuances.

Information elements common to the cases heard and ruled upon are:

Case name (owner(s) of facility)

Full text reference (volume and pagination)

Issuance number

Issues raised by appellants

Legal citations (cases, regulations, and statutes)

Name of facility, Docket number

Subject matter of issues and/or rulings

Type of hearing (operating license, operating license amendment, etc.)

Type of issuance (memorandum, order, decision, etc.)

These information elements are displayed in one or more of five separate formats arranged as follows:

\section{Case Name Index}

The case name index is an alphabetical arrangement of the case names of the issuances. Each case name is followed by the type of hearing, the type of issuance, docket number, issuance number, and full text reference.

\section{Headers and Digests}

The headers and digests are presented in issuance number order as follows: the Commission (CLI), the Atomic Safety and Licensing Board Panel (LBP), the Administrative Law Judges (ALJ), the Directors' Decisions (DD), and the Decisions on Petitions for Rulemaking (DPRM).

The header identifies the issuance by issuance number, case name, facility name, docket number, type of hearing, date of issuance, and type of issuance.

The digest is a brief narrative of an issue followed by the resolution of the issue and any legal references used in resolving the issue. If a given issuance covers more than one issue, then separate digests are used for each issue and are designated alphabetically.

\section{Legal Citations Index}

This index is divided into four parts and consists of alphabetical or alpha-numerical arrangements of Cases, Regulations, Statutes, and Others. These citations are listed as given in the issuances. Changes in regulations and statutes may have occurred to cause changes in the number or name and/or applicability of the citation. It is therefore important to consider the date of the issuance.

The references to cases, regulations, statutes, and others are generally followed by phrases that show the application of the citation in the particular issuance. These phrases are followed by the issuance number and the full text reference. 


\section{Subject Index}

Subject words and/or phrases, arranged alphabetically, indicate the issues and subjects covered in the issuances. The subject headings are followed by phrases that give specific information about the subject, as discussed in the issuances being indexed. These phrases are followed by the issuance number and the full text reference.

\section{Facility Index}

This index consists of an alphabetical arrangement of facility names from the issuance. The name is followed by docket number, type of hearing, date, type of issuance, issuance number, and full text reference. 


\section{DISCLAMMER}

Portions of this document may be illegible in electronic image products. Images are produced from the best available original doccument. 


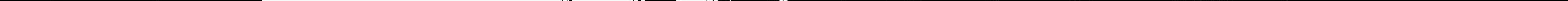




\section{CASE NAME INDEX}

CONSUMERS POWER COMPANY

REQUEST FOR ACTION; DIRECTOR'S DECISION UNDER 10 C.F.R. \$2.206; Docket Nos. 50-255, 72-7; DD-97-1, 45 NRC 33 (1997); DD-97-5, 45 NRC 135 (1997)

ENTERGY OPERATIONS, INC.

REQUEST FOR ACTION; DIRECTOR'S DECISION UNDER 10 C.F.R. $\$ 2.206$; Docket Nos. 50-313, 50-368, 72-13; DD-97-5, 45 NRC 135 (1997)

ENVIROCARE OF UTAH, INC.

REQUEST FOR ACTION; DIRECTOR'S DECISION UNDER 10 C.F.R. \$2.206; Docket No. $40-8989$ (License No. SMC-1559); DD-97-2, 45 NRC 63 (1997)

GENERAL PUBLIC UTILITIES NUCLEAR CORPORATION

OPERATING LICENSE AMENDMENT; MEMORANDUM AND ORDER (Ruling on Summary Disposition Motion); Docket No. 50-219-OLA (ASLBP No. 96-717-02-OLA); LBP-97-1, 45 NRC 7 (1997)

GEORGIA POWER COMPANY, et al.

REQUEST FOR ACTION; DIRECTOR'S DECISION UNDER 10 C.F.R. \$2.206; Docket Nos. 50-321, 50-366, 50-424, 50-425; DD-97-6, 45 NRC 144 (1997)

ILLINOIS POWER COMPANY and SOYLAND POWER COOPERATIVE

OPERATING LICENSE AMENDMENT; MEMORANDUM AND ORDER (Terminating Proceeding); Docket No. 50-461-OLA (ASLBP No. 97-725-01-OLA); LBP-97-4, 45 NRC 125 (1997)

LOUISIANA ENERGY SERVICES, L.P.

CONSTRUCTION PERMIT-OPERATING LICENSE PROCEEDING; PARTIAL INITIAL DECISION

(Resolving Contentions B and J.3); Docket No. 70-3070-ML (ASLBP No. 91-641-02-ML) (Special Nuclear Material License); LBP-97-3, 45 NRC 99 (1997)

MATERIALS LICENSE; ORDER; Docket No. 70-3070-ML; CLI-97-2, 45 NRC 3 (1997); CLI-97-3, 45 NRC 49 (1997); CLI-97-4, 45 NRC 95 (1997)

NORTHEAST NUCLEAR ENERGY COMPANY

REQUEST FOR ACTION; DIRECTOR'S DECISION UNDER 10 C.F.R. \$2.206; Docket No. 50-245

(License No. DPR-21); DD-97-4, 45 NRC 86 (1997)

RALPH L. TETRICK

SPECIAL PROCEEDING; INITIAL DECISION; Docket No. 55-20726-SP (ASLBP No. 96-721-01-SP)

(Re: Operator License); LBP-97-2, 45 NRC 51 (1997)

SPECIAL PROCEEDING; CORRECTED COPY OF MEMORANDUM AND ORDER (Denial of Reconsideration, Stay); Docket No. 55-20726-SP (ASLBP No. 96-721-01-SP) (Re: Operator License); LBP-97-6, 45 NRC 130 (1997)

SEQUOYAH FUELS CORPORATION and GENERAL ATOMICS

ENFORCEMENT ACTION; MEMORANDUM AND ORDER; Docket No. 70-3070-ML; CLI-97-1, 45 NRC 1 (1997)

TOLEDO EDISON COMPANY, et al.

REQUEST FOR ACTION; DIRECTOR'S DECISION UNDER 10 C.F.R. \$2.206; Docket Nos. 50-346, 72-1004; DD-97-3, 45 NRC 71 (1997)

UNIVERSITY OF CINCINNATI

MATERIALS LICENSE AMENDMENT; MEMORANDUM AND ORDER (Dismissing Proceeding); Docket No. 30-02764-MLA (ASLBP No, 97-722-01-MLA); LBP-97-5, 45 NRC 128 (1997) 


\section{CASE NAME INDEX}

WESTINGHOUSE ELECTRIC CORPORATION

REQUEST FOR ACTION; DIRECTOR'S DECISION UNDER 10 C.F.R. $\$ 2.206$; DD-97-7, 45 NRC 258 (1997)

WISCONSIN ELECTRIC POWER COMPANY

REQUEST FOR ACTION; DIRECTOR'S DECISION UNDER 10 C.F.R. \$ 2.206; Docket Nos. 50-266, 50-301, 72-5; DD-97-5, 45 NRC 135 (1997) 


\section{DIGESTS \\ ISSUANCES OF THE NUCLEAR REGULATORY COMMISSION}

CLI-97-1 SEQUOYAH FUELS CORPORATION and GENERAL ATOMICS (Gore, Oklahoma Site Decontamination and Decommissioning Funding), Docket No. 40-8027-EA; ENFORCEMENT ACTION; January 22, 1997; MEMORANDUM AND ORDER

A

The Commission grants two petitions for review challenging the Licensing Board's approval of a settlement agreement. The Commission also establishes a briefing schedule.

CLI-97-2 LOUISIANA ENERGY SERVICES, L.P. (Claiborne Enrichment Center), Docket No. 70-3070-ML; MATERIALS LICENSE; January 29, 1997; ORDER

A The Commission denies a motion, filed by the Intervenor, requesting partial reconsideration of CLI96-8, 44 NRC 107 (1996). In CLI-96-8, the Commission granted in part and denied in part the Intervenor's petition for review of Atomic Safety and Licensing Board Initial Decision LBP-96-7, 43 NRC 142 (1996), which resolved all contentions on emergency planning in the Applicant's favor.

B Motions for reconsideration may not rest on a new thesis that could have been raised earlier in a petition for review.

C NRC rules contemplate petitions for reconsideration of a Commission decision on the merits, not petitions for reconsideration of a Commission decision to decline review of an issue. See 10 C.F.R. $\$ 2.786(\mathrm{e})$.

CLI-97-3 LOUISIANA ENERGY SERVICES, L.P. (Claiborne Enrichment Center), Docket No. 70-3070-ML; MATERIALS LICENSE; February 13, 1997; ORDER

A The Commission grants petitions filed by the Staff and Louisiana Energy Services for Commission review of the Atomic Safety and Licensing Board Partial Initial Decision, LBP-96-25, 44 NRC 331 (1996), and sets a briefing schedule pursuant to 10 C.F.R. $\$ 2.786$ (d).

CLI-97-4 LOUISIANA ENERGY SERVICES, L.P. (Claiborne Enrichment Center), Docket No. 70-3070-ML; MATERIALS LICENSE; March 21, 1997; ORDER

A

The Commission grants Nuclear Energy Institute's motion for leave to file an amicus curiae brief in the appeal of the Atomic Safety and Licensing Board's second Partial Initial Decision, LBP-96-25, 44 NRC 331 (1996), and adjusts the briefing schedule and page limits for responsive and reply briefs. The Commission also grants Louisiana Energy Services' motion for the Commission to defer filing of petitions for review of the third Partial Initial Decision, LBP-97-3, 45 NRC 99 (1997).

B

"[A]n amicus curiae necessarily takes the proceeding as it finds it. An amicus curiae can neither inject new issues into a proceeding nor alter the content of the record developed by the parties." Public Service Co. of New Hampshire (Seabrook Station, Units 1 and 2), ALAB-862, 25 NRC 144, 150 (1987) (footnote omitted) 


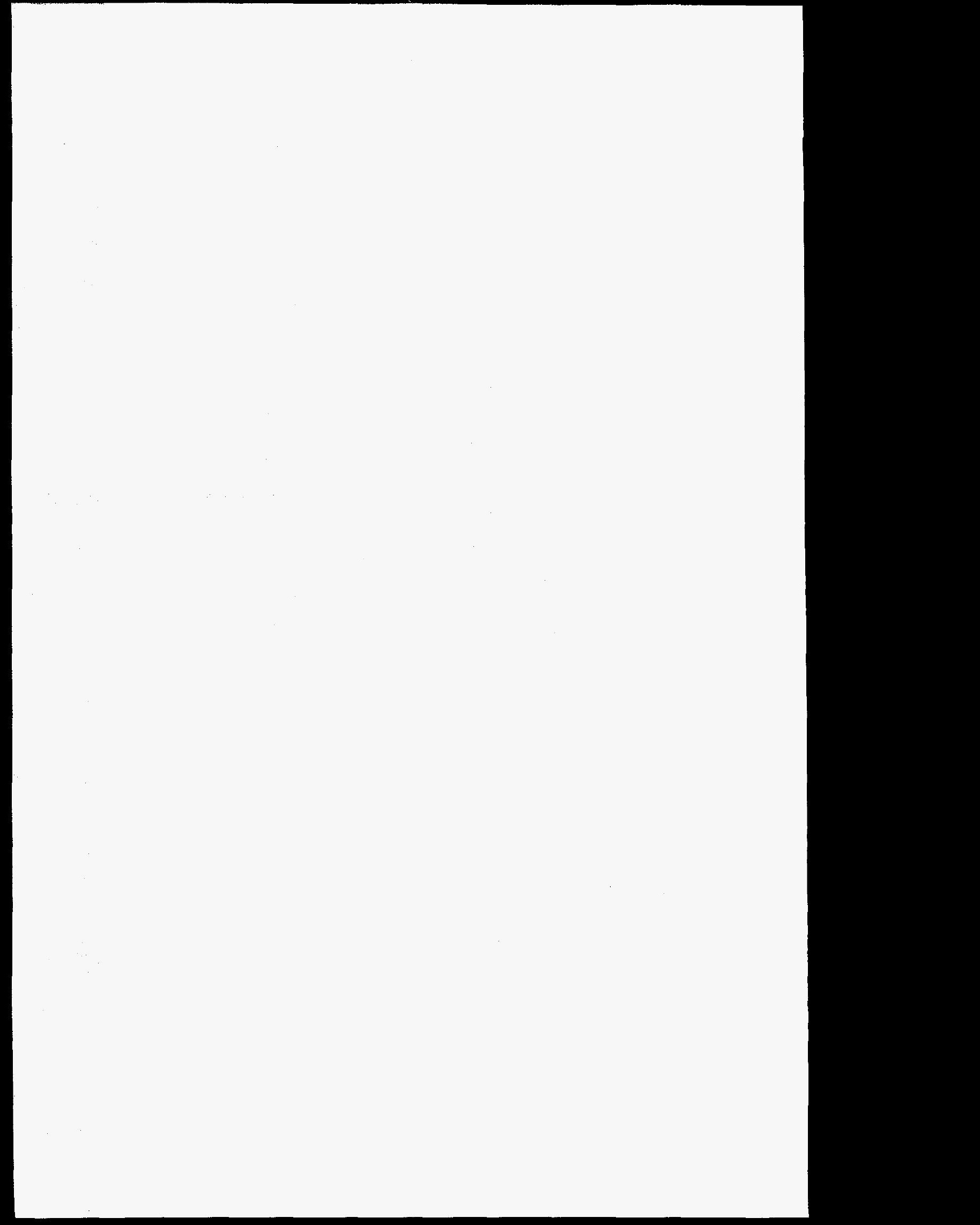




\title{
DIGESTS
}

\author{
ISSUANCES OF THE ATOMIC SAFETY AND LICENSING BOARDS
}

LBP-97-1 GENERAL PUBLIC UTILITIES NUCLEAR CORPORATION (Oyster Creek Nuclear Generating Station), Docket No. 50-219-OLA (ASLBP No. 96-717-02-OLA); OPERATING LICENSE AMENDMENT; January 31, 1997; MEMORANDUM AND ORDER (Ruling on Summary Disposition Motion) In this proceeding concerning challenges by Intervenors Nuclear Information Resource Service (NIRS) and the Oyster Creek Nuclear Watch (OCNW) to a technical specification change regarding heavy load handling over the Oyster Creek Nuclear Generating Station spent fuel pool, the Licensing Board grants summary disposition in favor of Licensee General Public Utilities Nuclear Corporation (GPUN) on the sole intervenor contention, ruling that (1) prior to the requested revision, the technical specification did preclude the heavy load activity now at issue; (2) as they embody the agency's "defense-in-depth" philosophy the provisions of NUREG-0612, "Control of Heavy Loads at Nuclear Power Plants" (July 1980), which Intervenors assert preclude authorizing the requested technical specification change, establish guidance rather than regulatory requirements for handling heavy loads; and (3) nothing in the provisions of NUREG-0612 and later NRC Staff generic letters intended to promote compliance with that document's recommendations bars the adoption of the requested technical specification change.

The first interpretational tool for discerning the meaning of the terms of a license is the plain meaning of the language of the provision in question.

C

A subsequent enactment that declares the intent of an earlier provision generally is to be given "great weight" in resolving a construction problem. See Red Lion Broadcasting v. FCC. 395 U.S. 367, 38081 (1969); cf. 17A Am. Jur. 2d Contracts $\$ 388$, at 415-16 (1991) (when contract terms are ambiguous and parties have made other contracts concerning the same subject matter, those instruments can be examined together to aid in interpretation). The relevance of such a subsequent enactment seems particularly telling when the parties who drafted and approved the revision declare it was intended to clarify any ambiguity in the prior version.

In a technical specification paragraph that sets forth a general prohibition, the use of the term "except" to describe a specific activity sanctioned in a subsequent paragraph establishes that, but for its specification as an exception, that activity would be covered by the general prohibition.

E

A Staff report bearing the NUREG designation does not fall into the category of a regulatory "requirement," such as a statute, regulation, license condition, or order. See Curators of the University of Missouri, CLI-95-1, 41 NRC 71, 98 (1995). Instead, at best, "it serves as guidance, setting forth but one method for meeting the applicable regulatory requirements . . . . In other words, that document "is treated simply as evidence of a legitimate means for complying with regulatory requirements." Carolina Power and Light Co. (Shearon Harris Nuclear Power Plant), ALAB-852, 24 NRC 532, 544-45 (1986) (quoting Metropolitan Edison Co. (Three Mile Island Nuclear Station, Unit 1), ALAB-698, 16 NRC 1290, 1298-99 (1982), aff'd in part on other grounds, CLI-83-22, 18 NRC 299 (1983))

In a generic letter that both "requested" that licensees take various actions and "required" that licensees provide a report detailing their compliance efforts, in contrast to the reporting component of a generic letter, which seemingly would constitute a "requirement," see 10 C.F.R. $\$ \$ 2.204,50.54(f)$, the generic letter's compliance request would not constitute a "requirement" in the absence of some additional regulatory directive such as an order or a regulation mandating compliance. Cf. 60 Fed. Reg. 34,381, 34,392 (1995) (agency expects licensees to adhere to commitments resulting from administrative actions such as confirmatory action letters and will issue appropriate orders to ensure commitments are met), reprinted in 


\section{DIGESTS \\ ISSUANCES OF THE ATOMIC SAFETY AND LICENSING BOARDS}

Office of Enforcement, U.S. Nuclear Regulatory Commission, NUREG-1600, "General Statement of Policy and Procedures for NRC Enforcement Actions" at 14 (July 1995).

G A technical specification that is not subject to revision would not be the norm. By providing in section 187 of the Atomic Energy Act that agency-issued licenses are "subject to amendment," 42 U.S.C. $\$ 2237$; see also, e.g., 10 C.F.R. $\$ 50.90$, the Congress contemplated that any license provision could be changed, at least so long as the revision sought was not inimical to the public health and safery or the common defense and security. Consequently, in the absence of language in the license (or some other regulatory requirement) that makes manifest a license provision's immutability, the question in a license amendment proceeding generally is whether the requested change is consistent with applicable agency regulatory strictures and any suitable guidance

LBP-97-2 RALPH L. TETRICK (Denial of Application for Reactor Operator License), Docket No. 55-20726SP (ASLBP No. 96-721-01-SP) (Re: Operator License); SPECIAL PROCEEDING; February 28, 1997 INITIAL DECISION

A The Presiding Officer determined that a reactor operator should be considered to have passed the written test for senior reactor operator.

B He determined that one of the questions on the exam was ambiguous and should be disallowed. He also determined, in the absence of guidance from the Staff of the Commission, that examination scores are sufficiently imprecise that they should be rounded to the nearest integer. As a consequence, the score on the written examination was $80 \%$, which the Presiding Officer considered a passing score. Since this was the last hurdle for the applicant in obtaining his ticense, the Presiding Officer directed the Staff to issue a Senior Reactor Operator's license to him.

LBP-97-3 LOUISIANA ENERGY SERVICES, L.P. (Claiborne Enrichment Center), Docket No, 70-3070ML (ASLBP No. 91-641-02-ML) (Special Nuclear Material License); CONSTRUCTION PERMITOPERATING LICENSE PROCEEDING; March 7, 1997; PARTIAL INITIAL DECISION (Resolving Contentions $B$ and $J .3$ )

A In this Partial Initial Decision in the combined construction permit-operating license proceeding for the Claiborne Enrichment Center, the Licensing Board resolves in favor of the Intervenor a portion of decommissioning funding contention B.1 and environmental contention J.3 concerning the conversion component of the estimated cost of tails disposal.

B The Commission's rules of practice for the conduct of formal adjudicatory hearings provide in 10 C.F.R. $\$ 2.732$ that the applicant has the burden of proof in the proceeding. Thus, in order for the applicant to prevail on each contested factual issue, the applicant's position must be supported by a preponderance of the evidence. Philadelphia Electric Co. (Limerick Generating Station, Units 1 and 2), ALAB-819, 22 NRC 681, 720 (1985); Pacific Gas and Electric Co. (Diablo Canyon Nuclear Power Plant, Units 1 and 2), ALAB-763, 19 NRC 571, 577 (1984). See 1 Charles H. Koch, Jr., Administrative Law and Practice \$6.44 (1985).

C The USEC Privatization Act, 42 U.S.C. $\$ 2297 \mathrm{~h}-11$ (a)(1)(B) now makes the Department of Energy, at the request of an NRC-licensed enricher, responsible for the disposal of depleted uranium tails at DOE's disposal costs, including a pro rata share of any of DOE's capital costs.

LBP-97-4 ILLINOIS POWER COMPANY and SOYLAND POWER COOPERATIVE (Clinton Power Station, Unit 1), Docket No. 50-461-OLA (ASLBP No. 97-725-01-OLA); OPERATING LICENSE AMENDMENT; March 11, 1997; MEMORANDUM AND ORDER (Terminating Proceeding)

A In this proceeding regarding the proposed transfer of the ownership share of Clinton Power Station minority owner Soyland Power Cooperative to majority owner Illinois Power Company, the Licensing Board grants the unopposed request of Petitioner Southwestern Electric Cooperative, Inc., to dismiss its protective intervention petition and terminate the proceeding.

B Simply because a filing is labeled a petition to intervene does not prevent the presiding officer from treating it as a request to initiate a hearing if this, in fact, is what the petitioner is seeking. See Yankee Atomic Electric Co. (Yankee Nuclear Power Station), CLI-96-1, 43 NRC 1, 5 (1996).

LBP-97-5 UNIVERSITY OF CINCINNATI (Denial of License Amendment), Docket No. 30-02764-MLA (ASLBP No. 97-722-01-MLA); MATERIALS LICENSE AMENDMENT; March 27, 1997; MEMORANDUM AND ORDER (Dismissing Proceeding) 


\section{DIGESTS}

ISSUANCES OF THE ATOMIC SAFETY AND LICENSING BOARDS

LBP-97-6 RALPH L. TETRICK (Denial of Application for Reactor Operator License), Docket No. 55-20726SP (ASLBP No. 96-721-01-SP) (Re: Operator License); SPECIAL PROCEEDING; March 27, 1997 ; CORRECTED COPY OF MEMORANDUM AND ORDER (Denial of Reconsideration, Stay)

A

The Presiding Officer denied the Staff's motion for reconsideration. He ruled that the Staff should reasonably have foreseen the importance of whether or not to round up applicant's examination score. Consequently, Staff should have raised this question earlier and it was untimely to do so in a Motion for Reconsideration. Since the Presiding Officer also concluded that there was no important safety issue involved, he used his discretion to deny the untimely motion. 


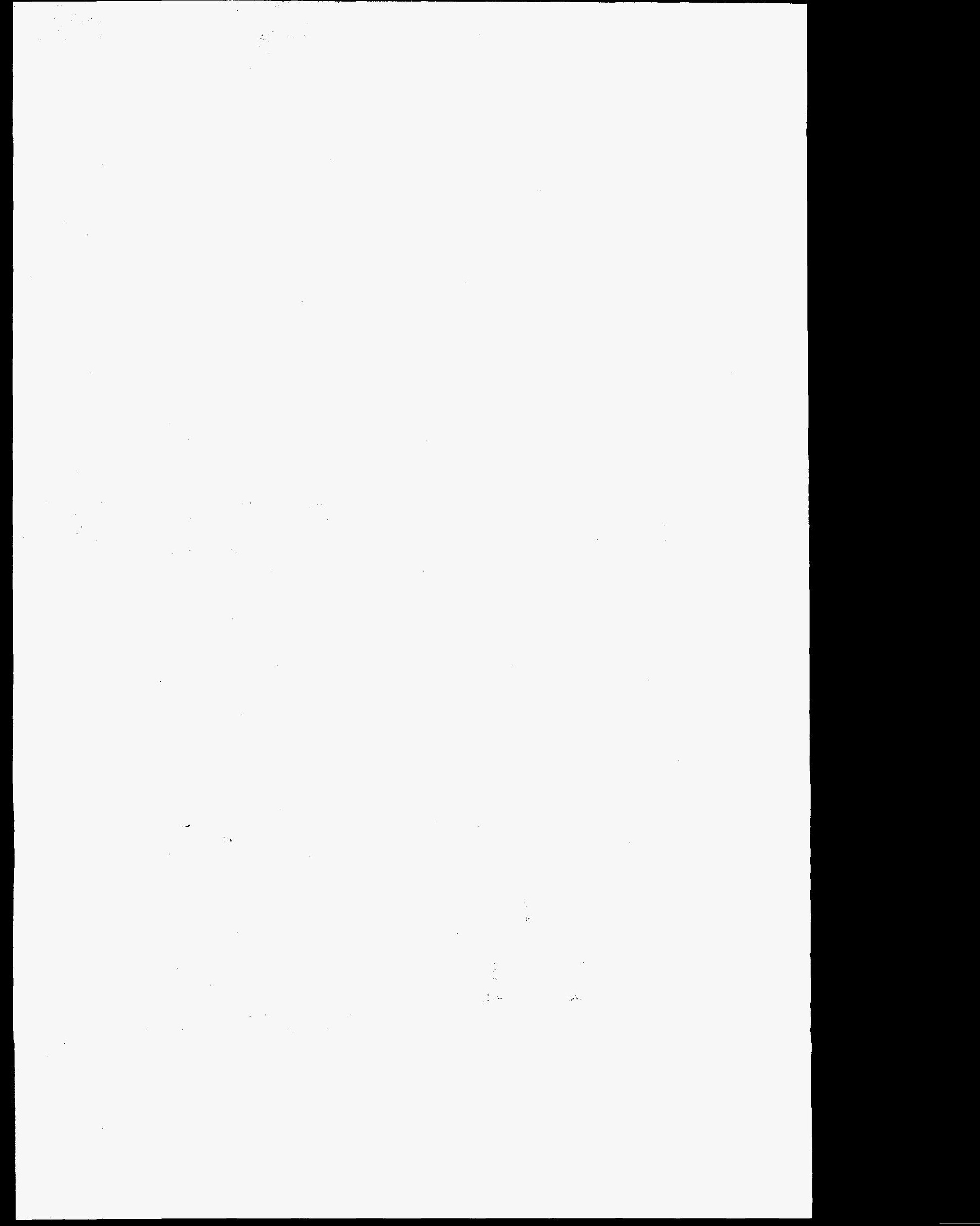




\section{DIGESTS}

ISSUANCES OF DIRECTORS' DECISIONS

DD-97-1 CONSUMERS POWER COMPANY (Palisades Nuclear Plant), Docket Nos. 50-255, 72-7; REQUEST FOR ACTION; January 23, 1997; DIRECTOR'S DECISION UNDER 10 C.F.R. $\$ 2.206$

A The Acting Director of the Office of Nuclear Reactor Regulation is granting, in part, and denying, in part, a petition filed by the organizations Don't Waste Michigan and Lake Michigan Federation pursuant to 10 C.F.R. \$2.206. The Petitioners requested that the NRC (1) find that Consumers Power Company violated NRC requirements related to unloading procedures for dry storage casks for spent nuclear fuel, (2) suspend the Licensee's use of the general license provisions related to dry cask storage of spent nuclear fuel, (3) require a substantial penalty be paid by the Licensee, and (4) conduct hearings related to unloading procedures for dry storage casks at Palisades. To the extent that the NRC has determined that Consumers Power Company violated NRC regulations insofar as the original unloading procedure developed for unloading dry storage casks was not adequate, the petition is granted. However, the NRC has decided not to impose a civil penalty for the violation or to suspend Consumers Power Company's use of the general license for dry cask storage at Palisades. To that extent, the petition is denied.

DD-97-2 ENVIROCARE OF UTAH, INC., Docket No. 40-8989 (License No. SMC-1559); REQUEST FOR ACTION; February 5, 1997; DIRECTOR'S DECISION UNDER 10 C.F.R. \$2.206

A The Director, Office of Nuclear Material Safety and Safeguards, has denied a petition filed by Dr. Thomas B. Cochran on behalf of Natural Resources Defense Council (NRDC) requesting that the NRC take action regarding Envirocare of Utah, Inc. (Envirocare). The petition requested that the NRC immediately revoke any license or cause the State of Utah (Utah) to revoke any Agreement State license or licenses held by Envirocare, its President, Khosrow Semnani, or any entity controlled or managed by Mr. Semnani; prohibit the future issuance of any license by the NRC, Utah, or other NRC Agreement State to Mr. Semnani or any entity controlled or managed by him or with which he has a significant affiliation; and suspend Utah's Agreement State status until it can demonstrate that it can operate its Division of Radiation Control in a lawful manner. As a basis for the petition, the Petitioner asserted that an article in the Salt Lake City Tribune reported secret cash payments made by Mr. Semnani to the Director of the Utah Division of Radiation Control, and Utah's initiation of a criminal investigation into the matter. The reasons for the denial are set forth in the Decision.

The Commission's regulations recognize that a licensee should be afforded under usual circumstances a prior opportunity to be heard before the agency suspends a license or takes other enforcement action, but that extraordinary circumstances may warrant summary action prior to hearing.

C

Since the inception of the 10 C.F.R. $\$ 2.206$ process, the Commission has consistently stated that the purpose of 10 C.F.R. $\$ 2.206$ is to provide the public with the means for participating in the enforcement process.

In accordance with the Commission's determination that the section 2.206 process should be focused on requests for enforcement action rather than an evaluation of safety concerns, petitions will be reviewed under 10 C.F.R. $\$ 2.206$ if the request is for enforcement action, and a request under section 2.206 should be distinguished from a request to deny a pending license application or amendment.

DD-97-3 TOLEDO EDISON COMPANY, et al. (Davis-Besse Independent Spent Fuel Storage Installation), Docket Nos. 50-346, 72-1004; REQUEST FOR ACTION; February 5, 1997; DIRECTOR'S DECISION UNDER 10 C.F.R. $\$ 2.206$

A The Director of the Office of Nuclear Material Safety and Safeguards grants, in part, and denies, in part, a petition filed pursuant to 10 C.F.R. $\$ 2.206$ on behalf of the Toledo Coalition for Safe Energy, 


\section{DIGESTS}

ISSUANCES OF DIRECTORS' DECISIONS

Alice Hirt, Charlene Johnston, Dini Schut, and William Hoops. The petition is granted to the extent that the NRC has initiated a rulemaking to modify the Certificate of Compliance for the VECTRA Technologies NUHOMS-24P dry-shielded canisters (DSCs) in order to require fabrication inspection. The Petitioners' request that the NRC require the unloading of DSCs pending completion of the rulemaking is denied. The Director also finds no basis for taking any further enforcement action against VECTRA or to require the halting of the ISFSI operation at Davis-Besse.

DD-97-4 NORTHEAST NUCLEAR ENERGY COMPANY (Millstone Nuclear Power Station, Unit 1) Docket No. 50-245 (License No. DPR-21); REQUEST FOR ACTION; February 11, 1997; DIRECTOR'S DECISION UNDER 10 C.F.R. $\$ 2.206$

A . The Acting Director, Office of Nuclear Reactor Regulation, has granted in part and denied in part a petition filed by Anthony J. Ross requesting action regarding Millstone Nuclear Power Station, Unit 1. The Petitioner requested that the Commission take escalated enforcement action against the Licensee and certain individuals based upon the deliberate failure to comply with procedures involving sign-out of measuring and test equipment, and conduct an investigation into alleged procedural violations and audit the Millstone Unit 1 maintenance department Measuring and Test Equipment folders for widespread problems regarding procedural noncompliance. To the extent that the Petitioner requested escalated enforcement action be taken, the petition has been denied; to the extent that the Petitioner requested an investigation into the procedural violations and an audit, the petition has been granted.

Minor violations, as described in the current enforcement policy, are not the subject of formal enforcement action and are usually not cited in inspection reports. To the extent that such violations are described, they are now noted as noncited violations.

The institution of a proceeding pursuant to 10 C.F.R. $\$ 2.206$ is appropriate only if substantial health and safety issues have been raised.

DD-97-5 CONSUMERS POWER COMPANY (Palisades Nuclear Plant), Docket Nos. 50-255, 72-7; EN TERGY OPERATIONS, INC. (Arkansas Nuclear One, Units 1 and 2), Docket Nos. 50-313, 50-368, 72-13; WISCONSIN ELECTRIC POWER COMPANY (Point Beach Nuclear Plant, Units 1 and 2), Docket Nos. 50-266, 50-301, 72-5; REQUEST FOR ACTION; March 4, 1997; DIRECTOR'S DECISION UNDER 10 C.F.R. $\$ 2.206$

A The Director of the Office of Nuclear Reactor Regulation denies the request by Petitioner Fawn Shillinglaw, filed pursuant to 10 C.F.R. $\$ 2.206$, that the NRC take action to prohibit loading of VSC-24 casks at any nuclear site until the multiassembly sealed basket \#4 at the Palisades nuclear plant has been unloaded and the experience evaluated for potential safety improvements. The Director concludes that the NRC will not permit unloading of any casks until it obtains reasonable assurance, through a variety of means, of each licensee's ability to do so safely, and therefore need not suspend any licensee's use of the general license for dry cask storage until the multiassembly sealed basket at Palisades has been unloaded.

DD-97-6 GEORGIA POWER COMPANY, et al. (Vogtle Electric Generating Plant, Units 1 and 2; Hatch Nuclear Plant, Units 1 and 2), Docket Nos. 50-321, 50-366, 50-424, 50-425; REQUEST FOR ACTION: March 18, 1997; DIRECTOR'S DECISION UNDER 10 C.F.R. $\$ 2.206$

A

The Acting Director, Office of Nuclear Reactor Regulation, has granted in part and denied in part a petition filed by Michael D. Kohn, Esquire, on behalf of Messrs. Marvin B. Hobby and Allen L. Mosbaugh requesting action regarding the Vogtle and Hatch nuclear facilities operated by Georgia Power Company and allegedly by the Southern Nuclear Operating Company (SONOPCO or Southern Nuclear). The petition raised concerns about the management practices of GPC and Southern Nuclear with respect to operation of the facilities, treatment of employees who raise concerns, provision of information to the NRC, and alleged false testimony before the Department of Labor. Petitioners requested the NRC to take immediate steps to determine if GPC's current management has the requisite character, competence, fundamental trustworthiness, and commitment to safety to continue operating a nuclear facility.

B Some concerns raised by the petition were partially substantiated. Violations of regulatory requirements occurred. The petition was granted to the extent that: the NRC issued three Notices of Violation and civil penalties to GPC for certain violations, the NRC issued letters to GPC (and GPC and SONOPCO employees) regarding the requirements of 10 C.F.R. $\$ 50.7$ and 50.9, the license transfe amendment proceeding evaluated many of the concerns, and the license transfer amendments issued for the facilities were conditioned to address concerns about management. The petition was denied to the extent that 


\section{DIGESTS \\ ISSUANCES OF DIRECTORS' DECISIONS}

the Acting Director determined that no unauthorized transfer of the Vogtle operating licenses has occurred, and concluded that none of the issues call into question the Licensee's character, competence, fundamental trustworthiness, or commitment to safety in the operation of its nuclear facilities. Therefore, further action with respect to the issues raised in the petition was denied.

The general standard for integrity is whether there is reasonable assurance that the licensee has sufficient character to operate the plant in a manner consistent with public health and safety and applicable NRC requirements. The Commission may consider the acts of the licensee (and its employees) that have a rational connection to safe operation of a nuclear power plant.

DD-97-7 WESTINGHOUSE ELECTRIC CORPORATION (Madison, Pennsylvania); REQUEST FOR ACTION; March 20, 1997; DIRECTOR'S DECISION UNDER 10 C.F.R. \$2.206

A The Director, Office of Enforcement, has taken action with regard to a petition filed by Shannon Doyle requesting that the Commission take action with regard to Westinghouse Electric Corporation. The Petitioner requested that the Commission investigate allegations that Westinghouse willfully provided false information to the Department of Labor (DOL), institute a show-cause proceeding pursuant to 10 C.F.R. $\$ 2.202$, and/or impose a civil penalty upon Westinghouse. The Petitioner had asserted, as a basis for his request, that Westinghouse had failed to correct the DOL record and provided material false statements to the DOL Administrative Law Judge in a case arising under the Energy Reorganization Act. In denying the petition, the Director determined that the matter should be referred to the DOL Administrative Review Board for its consideration.

B

The NRC generally does not have specific requirements for qualification and training of health physics technicians.

C The NRC and DOL have complementary responsibilities in the area of employee protection. 


\section{LEGAL CITATIONS INDEX}

CASES

Advanced Medical Systems, Inc. (One Factory Row, Geneva, Ohio 44041), CLI-94-6, 39 NRC 285, 299 (1994)

hearing rights on enforcement actions; DD-97-2, 45 NRC 68 (1997)

Alfred J. Morabito (Senior Operator License for Beaver Valley Power Station, Unit 1), LBP-88-10, 27 NRC 417 (1988); LBP-88-16, 27 NRC 583 (1988)

purpose of reactor operator examinations; LBP-97-2, 45 NRC 52 (1997)

Ardestani v. INS, 112 S. Ct. 515, 116 L. Ed. 2d 496 (1991) plain-language standard for interpretation of regulatory guidance; LBP-97-6, 45 NRC 132 n.3 (1997)

Biue Cross and Blue Shield of Alabama v. Weitz, 913 F.2d 1544, 1548, reh'g denied, 921 F.2d 283 (1990) interpretation of regulatory guides; LBP-97-6, 45 NRC 132 n.3 (1997)

Carolina Power and Light Co. (Shearon Harris Nuclear Power Plant), ALAB-852, 24 NRC 532, 544-45 (1986) application and status of regulatory guides; LBP-97-1, 45 NRC 25 (1997)

Central Electric Power Cooperative (Virgil C. Summer Nuclear Station, Unit 1), CLI-81-26, 14 NRC 787, 790 (1981)

motions for reconsideration resting on a new thesis; CLI-97-2, 45 NRC 4 (1997)

Consolidated Edison Co. of New York (Indian Point, Units 1, 2, and 3), CLI-75-8, 2 NRC 173, 175 (1975)

standard for institution of show-cause proceedings; DD-97-4, 45 NRC $92-93$ (1997)

Consumers Power Co. (Midland Plant, Units 1 and 2), ALAB-235, 8 AEC 645 (1974)

licensing board jurisdiction where motion for reconsideration has been filed; LBP-97-6, 45 NRC 131 (1997)

Curators of the University of Missouri, CLI-95-1, 41 NRC 71, 98 (1995) application and status of regulatory guides; LBP-97-1, 45 NRC 25 (1997)

Houston Lighting and Power Co. (South Texas Project, Units 1 and 2), CLI-80-32, 12 NRC 281, 291 (1980)

licensee abdication of responsibility or knowledge as basis for license revocation; DD-97-6, 45 NRC 155 (1997)

Metropolitan Edison Co. (Three Mile Island Nuclear Station, Unit 1), ALAB-698, 16 NRC 1290, 1298-99 (1982), aff'd in part on other grounds, CLI-83-22, 18 NRC 299 (1983) application and status of regulatory guides; LBP-97-1, 45 NRC 25 (1997)

Metropolitan Edison Co. (Three Mile Island Nuclear Station, Unit 1), CLI-85-9, 21 NRC 1118, 1136-37 (1985)

standards for management character and competence; DD-97-6, 45 NRC 155 (1997)

Pacific Gas and Electric Co. (Diablo Canyon Nuclear Power Plant, Units 1 and 2), ALAB-763, 19 NRC 571, 577 (1984) burden of proof on applicants; LBP-97-3, 45 NRC 104 (1997)

Philadelphia Electric Co. (Limerick Generating Station, Units 1 and 2), ALAB-819, 22 NRC 681, 706 (1985)

supplementation of final environmental impact statement by decision and adjudicatory record; LBP-97. 3, 45 NRC 123 (1997) 


\section{LEGAL CITATIONS INDEX \\ CASES}

Philadelphia Electric Co. (Limerick Generating Station, Units 1 and 2), ALAB-819, 22 NRC 681, 720 (1985)

burden of proof on applicants; LBP-97-3, 45 NRC 104 (1997)

Public Service Co. of New Hampshire (Seabrook Station, Units 1 and 2), ALAB-862, 25 NRC 144, 150 (1987)

participation by amicus curiae; CLI-97-4, 45 NRC 96 (1997)

Public Service Co. of New Hampshire (Seabrook Station, Units 1 and 2), CLI-88-10, 28 NRC 573, 587 (1988)

content of decommissioning funding plans; LBP-97-3, 45 NRC 118 (1997)

Randall C. Orem, D.O., CLI-93-14, 37 NRC 423, 427-28 (1993)

definition of material false statement; DD-97-6, 45 NRC 156 (1997)

Red Lion Broadcasting v. FCC, 395 U.S. 367, 380-81 (1969)

weight given to subsequent enactments in construction of terms of license; LBP-97-1, 45 NRC 19 (1997)

Reich Geo-Physical, Inc., ALJ-85-1, 22 NRC 941, 962-63 (1985)

interpretation of "careless disregard"; DD-97-6, 45 NRC 156 (1997)

Rodger W. Ellingwood (Senior Operator License for Catawba Nuclear Station), LBP-89-21, 30 NRC 68 (1989)

purpose of reactor operator examinations; LBP-97-2, 45 NRC 52 (1997)

Sequoyah Fuels Corp. (Gore, Oklahoma Site), CLI-94-12, 40 NRC 64, 71 (1994) standard for review of settlements; CLI-97-1, 45 NRC 2 (1997)

State of Utah (Agreement Pursuant to Section 274 of the Atomic Energy Act of 1954, as Amended), DD-95-1, 41 NRC 43 (1995)

scope of section 2.206 process; DD-97-2, 45 NRC 65 n.1 (1997)

Tennessee Valley Authority (Hartsville Nuclear Plant, Units 1A, 2A, 1B, and 2B), ALAB-418, 6 NRC 1, 2 (1977)

motions for reconsideration resting on a new thesis; CLI-97-2, 45 NRC 4 (1997)

Texas Utilities Electric Co. (Comanche Peak Steam Electric Station, Units 1 and 2), LBP-84-10, 19 NRC $509,517-18(1984)$

new arguments or evidence in motions for reconsideration; LBP-97-6, 45 NRC 131 (1997)

Trans World Airlines, Inc. v. Thurston, 83 L. Ed. 2d 523, 537 (1985)

interpretation of "careless disregard"; DD-97-6, 45 NRC 156 (1997)

Vermont Yankee Nuclear Power Corp. (Vermont Yankee Nuclear Power Station), CLI-74-40, 8 AEC 809, 813 (1974)

defense-in-depth principle; LBP-97-1, 45 NRC 20 n.7 (1997)

Virginia Electric and Power Co. (North Anna Power Station, Units 1 and 2), CLI-76-22, 4 NRC 480, 486, 491 (1976) aff'd sub nom. Virginia Electric and Power Co. v. NRC, 571 F.2d 1289 (4th Cir. 1978) licensee communications with NRC, importance of; DD-97-6, 45 NRC 156 (1997)

Washington Public Power Supply System (WPPSS Nuclear Project No. 2), DD-84-7, 19 NRC 899, 924 (1984)

standard for institution of show-cause proceedings; DD-97-4, 45 NRC 93 (1997)

Yankee Atomic Electric Co. (Yankee Nuclear Power Station), CLI-96-1, 43 NRC 1, 5 (1996) treatment of minority owner's protective intervention petition as request for hearing; LBP-97-4, 45 NRC 126 n.l (1997)

Yankee Atomic Electric Co. (Yankee Nuclear Power Station), CLI-96-7, 43 NRC 235, 272 (1996) specificity required of petitions for review; CLI-97-2, 45 NRC 4 (1997)

Yankee Atomic Electric Co. (Yankee Nuclear Power Station), LBP-96-18, 44 NRC 86, 92-93, petition for review denied, CLI-96-9, 44 NRC 112 (1996)

procedural requirements governing summary disposition process; LBP-97-1, 45 NRC 14 (1997) 


\section{LEGAL CITATIONS INDEX REGULATIONS}

10 C.F.R. 1.1231

submission of hearing file in informal proceedings; LBP-97-2, 45 NRC 52 (1997)

10 C.F.R. 2.202(a)(5)

revocation of byproduct material license, circumstances appropriaie for; DD-97-2, 45 NRC 67 (1997)

10 C.F.R. 2.204

application and status of generic letters; LBP-97-1, 45 NRC 26 n.10 (1997)

10 C.F.R. 2.206

design deficiencies in NUHOMS dry-shielded canisters; DD-97-3, 45 NRC 71-85 (1997)

licensee bribery of agreement state Radiation Control Director; DD-97-2, 45 NRC 64-70 (1997)

management character and competence; DD-97-6, 45 NRC 147-257 (1997)

measuring and test equipment sign-out procedures, violations of; DD-97-4, 45 NRC 86-93 (1997)

qualification and training of health physics technicians; DD-97-7, 45 NRC 258 (1997)

unloading of multiassembly basket of VSC-24 dry storage casks, reasonable assurance of safety of procedures for: DD-97-5, 45 NRC 136-43 (1997)

unloading procedures for dry storage casks, violations of requirements for; DD-97-1, 45 NRC 33-47 (1997)

10 C.F.R. 2.710

computation of time for petitions for review of decision served by mail; LBP-97-6, 45 NRC 133 (1997) deadline for filing petition for review of initial decision; LBP-97-2, 45 NRC 61 (1997)

service of initial decisions; LBP-97-2, 45 NRC 60 (1997)

10 C.F.R. 2.712(e)

date of service for petitions for review; LBP-97-6, 45 NRC 133 (1997)

service of initial decisions; LBP-97-2, 45 NRC 60 (1997)

10 C.F.R. 2.714(a)

challenges to technical specification changes; LBP-97-1, 45 NRC 11 (1997)

late-filing requirements for new basis for contention; LBP-97-1, 45 NRC 18 (1997)

10 C.F.R. 2.714(b)(2)

challenges to technical specification changes; LBP-97-1, 45 NRC 11 (1997)

10 C.F.R. $2.715(\mathrm{c})$

interested-state request for license conditions; LBP-97-3, 45 NRC 123 (1997)

10 C.F.R. 2.732

burden of proof on applicants; LBP-97-3, 45 NRC 104 (1997)

10 C.F.R. 2.749(a)

procedural requirements governing summary disposition process; LBP-97-1, 45 NRC 14 (1997)

10 C.F.R. 2.749 (d)

standard for seeking summary disposition; LBP-97-1, 45 NRC 13 (1997)

10 C.F.R. 2.754(b)

default on issues not included in intervenor's findings at hearing; LBP-97-3, 45 NRC 119 n.13 (1997)

10 C.F.R. 2.760

finality of decision on operating license amendment; LBP-97-1, 45 NRC 30 (1997)

finality of partial initial decision; LBP-97-3, 45 NRC 124 (1997) 


\section{LEGAL CITATIONS INDEX \\ REGULATIONS}

10 C.F.R. 2.771

licensing board jurisdiction where motion for reconsideration has been filed; LBP-97-6, 45 NRC 131 (1997)

10 C.F.R. 2.786

content of petitions for review and responses; LBP-97-2, 45 NRC 61 (1997); LBP-97-6, 45 NRC 133 (1997)

deadline for filing petitions for review; LBP-97-2, 45 NRC 60 (1997); LBP-97-6, 45 NRC 133 (1997) effect of petition for review on finality of decision; LBP-97-3, 45 NRC 124 (1997)

10 C.F.R. $2.786(\mathrm{~b})(1)$

deadline for petitions for review of decision on operating license amendment; LBP-97-1, 45 NRC 30 (1997)

schedule adjustments for response to amicus curiae; CLI-97-4, 45 NRC 97 (1997)

10 C.F.R. $2.786($ b) $(2)-(3)$

content of review briefs and answers; LBP-97-1, 45 NRC 31 (1997); LBP-97-3, 45 NRC 124 (1997)

10 C.F.R. $2.786(b)(3)$

schedule adjustments for response to amicus curiae; CLI-97-4, 45 NRC 97 (1997)

10 C.F.R. $2.786(b)(4)$

deadline for petitions for review; LBP-97-3, 45 NRC 124 (1997)

grounds for petitions for review; LBP-97-1, 45 NRC 30 (1997)

review of licensing board ruling on settlement agreement; CLI-97-1, 45 NRC 1 (1997)

standard for grant of review of partial initial decision on enrichment facility licensing; CLI-97-3, 45 NRC 49 (1997)

10 C.F.R. $2.786(\mathrm{~d})$

briefing schedule for review of licensing board ruling on settlement agreement; CLI-97-1, 45 NRC 1 (1997)

briefing schedule for review of partial initial decision on enrichment facility licensing; CLI-97-3, 45 NRC 49 (1997)

10 C.F.R. $2.786(\mathrm{e})$

reconsideration of Commission decision to decline review; CLI-97-2, 45 NRC 5 (1997)

10 C.F.R. 2.1201(a)(2)

informal proceeding on reactor operator examination results; LBP-97-2, 45 NRC 52 (1997)

10 C.F.R. 2.1233

written presentations in informal proceedings; LBP-97-2, 45 NRC 52 (1997)

10 C.F.R. 2.125

finality of initial decisions; LBP-97-2, 45 NRC 60 (1997); LBP-97-6, 45 NRC 133 (1997)

10 C.F.R. Part 2, Appendix C, V.A

NRC discretion in issuing Notice of Violation for isolated severity level $V$ violation; DD-97-6, 45 NRC 165 (1997)

10 C.F.R. Part 2, Appendix C, V.G.1

circumstances under which NRC need not issue a Notice of Violation for severity level IV or V violations; DD-97-6, 45 NRC 165, 167, 168 (1997)

10 C.F.R. Part 2, Appendix C, V.G.5

NRC discretion to forego a Notice of Violation when violation is discovered as a result of corrective action for previous enforcement action; DD-97-6, 45 NRC 171 (1997)

10 C.F.R. 20.1301(a)(1)

amendment of byproduct materials license to allow increased dose to visitors of radiation therapy patients; LBP-97-5, 45 NRC 128 (1997)

10 C.F.R. Part 30

amendment of byproduct materials license to allow increased dose to visitors of radiation therapy patients; LBP-97-5, 45 NRC 128 (1997)

10 C.F.R. Part 35

qualification and training of health physics technicians; DD-97-7, 45 NRC 261 (1997) 


\section{LEGAL CITATIONS INDEX \\ REGULATIONS}

10 C.F.R. $40.31(j)(3)(i)$

brief-description requirement for offsite fire department training and qualifications; CLI-97-2, 45 NRC 5 (1997)

10 C.F.R. $40.36(a),(c)(1)$, (d), (e)(3)

content of decommissioning funding plan; LBP-97-3, 45 NRC 101 (1997)

10 C.F.R. 50.5

failure to comply with sign-out procedures for measuring and test equipment; DD-97-4, 45 NRC 87 (1997)

10 C.F.R. $50.33,50.34$

inclusion of budget review activities in final safety analysis report; DD-97-6, 45 NRC 242 (1997)

10 C.F.R. 50.54(f)

application and status of generic letters; LBP-97-1, 45 NRC 26 n.10 (1997)

10 C.F.R. $50.54(x)$

non-emergency deviation from technical specifications requiring NRC notification; DD-97-6, 45 NRC 157 (1997)

10 C.F.R. 50.59

engineering and safety evaluation of radioactive waste microfiltration system, adequacy of; DD-97-6, 45 NRC 171 (1997)

evaluation of multiassembly sealed basket cooling skid; DD-97-1, 45 NRC 41-42 (1997)

NRC policy on safety analysis of spent fuel canister design; DD-97-3, 45 NRC 81 n.16 (1997)

10 C.F.R. 50.72

notification of declaration of emergency event; DD-97-6, 45 NRC 157 (1997)

Red Phone notification, definition of; DD-97-6, 45 NRC 170 n.24 (1997)

10 C.F.R. 50.73

events for which written reports to NRC are required within 30 days; DD-97-6, 45 NRC 157, 166 n.23, 196 (1997)

10 C.F.R. 50.73(a)(1)

Licensee Event Report, allegation of material false statement in; DD-97-6, 45 NRC 192 (1997)

10 C.F.R. 50.73(b)(1), (3)

content of Licensee Event Reports; DD-97-6, 45 NRC 192 (1997)

10 C.F.R. 50.80

character and integrity required of NRC licensees; DD-97-6, 45 NRC 229 (1997)

10 C.F.R. 50.90

revision of technical specifications; LBP-97-1, 45 NRC 26 n.11 (1997)

10 C.F.R. 50.91-.92

issuance of license amendment upon finding of no significant hazards consideration; LBP-97-1, 45 NRC 11 n.2 (1997)

10 C.F.R. Part 50, Appendix A, §I, Criteria 2, 4, 5, 61

technical specification change involving heavy load handling over spent fuel pool, $45 \mathrm{NRC} 27 \mathrm{n} .11$ (1997)

10 C.F.R. Part 50, Appendix B, Criteria V and VI

deficiencies in dry-cask unloading procedure as violation of; DD-97-1, $45 \mathrm{NRC} 38,40,43$ (1997)

10 C.F.R. 51.102

supplementation of final environmental impact statement by decision and adjudicatory record; LBP-97-3, 45 NRC 123 (1997)

10 C.F.R. 55.4

definition of senior reactor operator; LBP-97-2, 45 NRC 52 (1997)

10 C.F.R. 55.41(b)(1)-(14)

scope of written examination questions for senior reactor operator licenses; LBP-97-2, 45 NRC 52 (1997)

10 C.F.R. 55.43

responsibility for developing and administering reactor operator license examinations; LBP-97-2, 45 NRC 52 (1997) 


\section{LEGAL CITATIONS INDEX \\ REGULATIONS}

10 C.F.R. 55.43(a)

scope of written examination questions for reactor operator licenses; LBP-97-2, 45 NRC 52 (1997)

10 C.F.R. $55.43($ b) (1)-(7)

scope of written examination questions for senior reactor operator licenses; LBP-97-2, 45 NRC 52 (1997)

10 C.F.R. 55.45

responsibility for developing and administering reactor operator license examinations; LBP-97-2, 45 NRC 52 (1997)

scope of operating test for senior reactor operator licenses; LBP-97-2, 45 NRC 52 (1997)

10 C.F.R. Part 60

classification of depleted uranium tails for disposal purposes; LBP-97-3, 45 NRC 109 (1997)

10 C.F.R. Part 61

deep disposal site as most likely for uranium tails disposal; LBP-97-3, 45 NRC 107, 108 (1997)

10 C.F.R. $61.55(\mathrm{a})(2)$ (iv)

availability of deep burial for uranium tails disposal; LBP-97-3, 45 NRC 108 (1997)

10 C.F.R. $61.55(\mathrm{a})(3)$

classification of depleted uranium tails for disposal purposes; LBP-97-3, 45 NRC 109 (1997)

10 C.F.R. 61.55(a)(6)

classification of depleted uranium tails for disposal purposes; LBP-97-3, 45 NRC 109 (1997)

10 C.F.R. $70.22(\mathrm{i})(3)(\mathrm{i})$

brief-description requirement for offsite fire department training and qualifications; CLI-97-2, 45 NRC 5 (1997)

10 C.F.R. 70.25(a), (e)

content of decommissioning funding plan; LBP-97-3, 45 NRC 101 (1997)

10 C.F.R. Part 72

suspension of general license for dry-cask unloading procedure deficiencies; DD-97-1, 45 NRC 43,46 (1997)

10 C.F.R. 72.48

changes to design of dry storage cask for spent fuel; DD-97-3, 45 NRC 73 n.5 (1997)

10 C.F.R. 72.122(h), (l)

considerations in development of dry-cask unloading procedures; DD-97-1, 45 NRC 39 (1997)

10 C.F.R. Part 72, Subpart G

quality assurance for independent spent fuel storage installations; DD-97-1, 45 NRC 38 n.4 (1997)

10 C.F.R. 72.150

deficiencies in dry-cask unloading procedure as violation of; DD-97-1, 45 NRC 38 n.4 (1997) documentation requirements for quality-related activities; DD-97-3, 45 NRC 80 (1997)

10 C.F.R. 72.152

deficiencies in dry-cask unloading procedure as violation of; DD-97-1, 45 NRC $38 \mathbf{n . 4}$ (1997)

10 C.F.R. Part 72, Subpart K

authority to store spent fuel in dry-cask storage system on site; DD-97-1, 45 NRC 34 (1997); DD-97-5, 45 NRC 136 (1997)

10 C.F.R. $72.210,72.212$

authorization for onsite storage of spent nuclear fuel; DD-97-3, 45 NRC 72 (1997)

10 C.F.R. $72.212(\mathrm{a})(2)$

use of certified casks for onsite storage of spent tuclear fuel; DD-97-3, 45 NRC $80 \mathrm{n} .15$ (1997)

10 C.F.R. 72.212(b)

applicability of Certificate of Compliance terms and conditions to general licensee; DD-97-3, 45 NRC $83(1997)$

10 C.F.R. $72.212(\mathrm{~b})(2)$

deficiencies in dry-cask unloading procedure as violation of; DD-97-1, 45 NRC 37 (1997)

10 C.F.R. $72.212(\mathrm{~b})(9)$

licensee responsibility to prepare, review, approve, and test written procedures for dry-cask loading and unloading; DD-97-3, 45 NRC 83 (1997) 


\section{LEGAL CITATIONS INDEX \\ REGULATIONS}

10 C.F.R. 72.214

approval procedure for spent fuel storage casks; DD-97-3, 45 NRC 80 n.15 (1997)

10 C.F.R. 72.230

Safety Analysis Report requirement for vendors seeking NRC approval of spent fuel storage casks; DD-97-3, 45 NRC 73 n.4 (1997)

10 C.F.R. 72.232

NRC inspection of vendors' facilities where dry storage casks are fabricated; DD-97-3, 45 NRC 73 (1997)

10 C.F.R. $72.236(\mathrm{~b})$

content of SAR for vendors seeking NRC approval of spent fuel storage casks; DD-97-3, 45 NRC 77 n.9, 78 n.11 (1997)

10 C.F.R. 72.236(h)

considerations in development of dry-cask unloading procedures; DD-97-1, 45 NRC 39 (1997)

10 C.F.R. 73.71

Red Phone notification, definition of; DD-97-6, 45 NRC 170 n.24 (1997)

10 C.F.R. Part 100

offsite dose consequences for heavy load handling over spent fuel pool; LBP-97-1, 45 NRC 16, 21, 28, 29 n.16 (1997)

29 C.F.R. Part 24

discrimination against employees for engaging in protected activities; DD-97-6, 45 NRC 223 (1997) 


\section{LEGAL CITATIONS INDEX STATUTES}

Atomic Energy Act, 182, 42 U.S.C. $\$ 2232$

character and integrity required of NRC licensees; DD-97-6, 45 NRC 229 (1997)

Atomic Energy Act 187, 42 U.S.C. $\$ 2237$

revision of technical specifications; LBP-97-1, 45 NRC 26 n.11 (1997)

Atomic Energy Act, 189a(1)(A), (2)(A), 42 U.S.C. \& 2239(a)(1)(A), (2)(a)

issuance of license amendment upon finding of no significant hazards consideration; LBP-97-1, 45 NRC 11 n.2 (1997)

Energy Reorganization Act, 210, 42 U.S.C. $\$ 5851$

discrimination against employees for engaging in protected activities; DD-97-6, 45 NRC 223 (1997) discrimination in matter of qualification and training of health physics technician; DD-97-7, $45 \mathrm{NRC}$ 260 (1997)

Low Level Radioactive Waste Policy Act, 42 U.S.C. $\$ 2021 \mathrm{~b}$ et seq.

plausibility of applicant's strategy for disposal of depleted uranium tails; LBP-97-3, 45 NRC $110 \mathrm{n} .7$ (1997)

USEC Privatization Act, Pub. L. No. 104-134, 100 Stat. 1321 (1996), 42 U.S.C. $\$ 2297 \mathrm{~h}-11$

disposal strategy for depleted uranium tails; LBP-97-3, 45 NRC 109 (1997)

USEC Privatization Act, 42 U.S.C. $\$ 2297 \mathrm{~h}-11$ (a), (c)

plausibility of applicant's strategy for disposal of depleted uranium tails; LBP-97-3, 45 NRC $110 \mathrm{n}$.7 (1997)

USEC Privatization Act, 42 U.S.C. $\S 2297 \mathrm{~h}-11$ (a)(1)(B), (a)(3)

DOE responsibility for disposal of depleted uranium tails; LBP-97-3, 45 NRC $110 \mathrm{n} .7$ (1997)

USEC Privatization Act, 42 U.S.C. $\$ 2297 \mathrm{~h}-11$ (b)

options for depleted uranium tails disposal; LBP-97-3, 45 NRC 110 (1997)

USEC Privatization Act, 42 U.S.C. \&2297h-11(c)

state liability for waste attributable to private uranium enrichment facility; LBP-97-3, 45 NRC 123 (1997) 


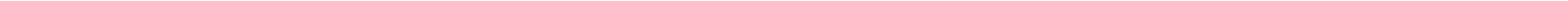




\section{LEGAL CITATIONS INDEX OTHERS}

17A Am. Jur. 2d Contracts $\$ 388$, at $415-16$ (1991)

weight given to subsequent enactments in construction of terms of license; LBP-97-1, 45 NRC 19 (1997)

Fed. R. Civ. P. 56(c)

standard for seeking summary disposition; LBP-97-1, 45 NRC 13 (1997)

1 Charles H. Koch, Jr., Administrative Law and Practice \$6.44 (1985)

burden of proof on applicants; LBP-97-3, 45 NRC 104 (1997)

Webster's Third New International Dictionary 1736 (1971)

definition of "plausible" and "strategy" relative to uranium tails disposal; LBP-97-3, 45 NRC 105 (1997) 


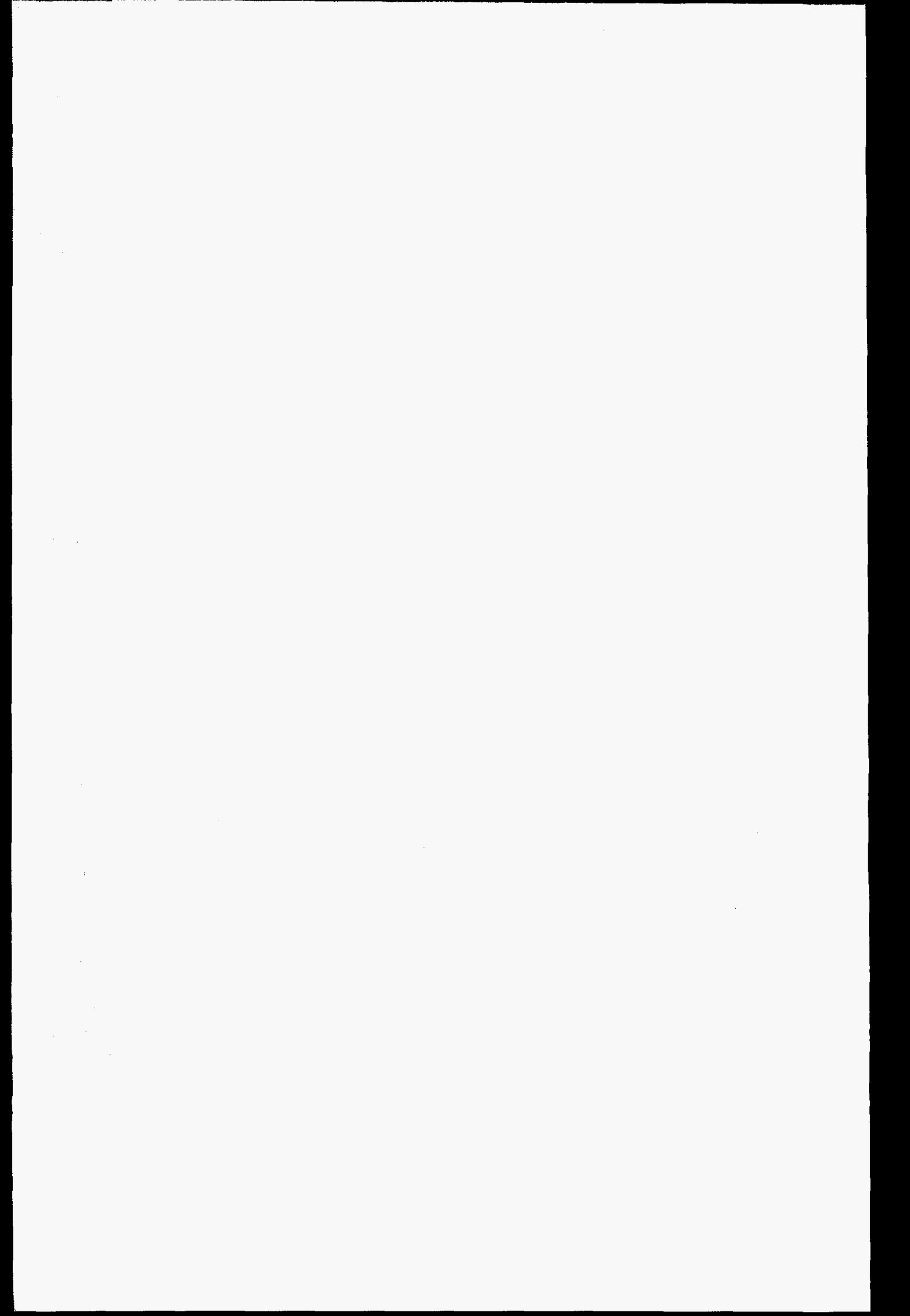




\section{SUBJECT INDEX}

AGREEMENT STATE

licensee bribery of state official; DD-97-2, 45 NRC 63 (1997)

AMENDMENT

See Byproduct Materials License Amendment; Operating License Amendments

AMICUS CURIAE

scope of participation; CLI-97-4, 45 NRC 95 (1997)

APPLICANTS

burden of proof on; LBP-97-3, 45 NRC 99 (1997)

ATOMIC ENERGY ACT

hearing rights on enforcement actions; DD-97-2, 45 NRC 63 (1997)

license amendments; LBP-97-1, 45 NRC 7 (1997)

licensing standards; DD-97-6, 45 NRC 144 (1997)

BRIEFS

schedule and page-limit adjustments for response and reply to amicus curiae; CLI-97-4, 45 NRC 95 (1997)

BRIEFS, APPELLATE

challenging licensing board approval of settlement agreement; CLI-97-1, 45 NRC 1 (1997)

scheduling of; CLI-97-3, 45 NRC 49 (1997)

specificity required in; CLI-97-2, 45 NRC 3 (1997)

BURDEN OF PROOF

on applicants; LBP-97-3, 45 NRC 99 (1997)

BYPRODUCT MATERIALS LICENSE

hearing rights on enforcement actions; DD-97-2, 45 NRC 63 (1997)

BYPRODUCT MATERIALS LICENSE AMENDMENT

to allow increased dose to visitors of radiation therapy patients; LBP-97-5, 45 NRC 128 (1997)

CERTIFICATE OF COMPLIANCE

applicability of terms and conditions to general licensees; DD-97-3, 45 NRC 71 (1997)

CONSTRUCTION OF TERMS

"except" in technical specifications; LBP-97-1, 45 NRC 7 (1997)

plain meaning of the language; LBP-97-1, 45 NRC 7 (1997)

subsequent revisions, weight given to; L.BP-97-1, 45 NRC 7 (1997)

CONTAINMENT ISOLATION VALVES

surveillance testing of; DD-97-6, 45 NRC 144 (1997)

CRITICALITY

of spent fuel in dry storage casks during unloading; DD-97-1, 45 NRC 33 (1997)

DECOMMISSIONING FUNDING

disposal of depleted uranium tails, reasonable assurance of; LBP-97-3, 45 NRC 99 (1997)

DECOMMISSIONING FUNDING PLANS

content of; LBP-97-3, 45 NRC 99 (1997)

DEFENSE-IN-DEPTH POLICY

technical specification changes and; LBP-97-1, 45 NRC 7 (1997)

DEPARTMENT OF ENERGY

responsibility for disposal of depleted uranium tails; LBP-97-3, 45 NRC 99 (1997) 


\section{SUBJECT INDEX}

\section{DEPARTMENT OF LABOR}

jurisdiction over employee protection; DD-97-7, 45 NRC 258 (1997)

DESIGN

of NUHOMS dry-shielded canisters for spent fuel storage; DD-97-3, 45 NRC 71 (1997)

DIESEL GENERATORS

reporting and reliability issues; DD-97-6, 45 NRC 144 (1997)

DILUTION VALVES

open when required to be closed; DD-97-6, 45 NRC 144 (1997)

DOSE

See Radiation Dose

DRY-CASK STORAGE

pressurization limits; DD-97-1, 45 NRC 33 (1997)

unloading of multiassembly basket of VSC-24 casks; DD-97-5, 45 NRC 135 (1997)

unloading procedures; DD-97-1, 45 NRC 33 (1997)

EMPLOYEE DISCRIMINATION

for engaging in protected activities; DD-97-6, 45 NRC 144 (1997)

ENFORCEMENT ACTION

hearing rights on; DD-97-2, 45 NRC 63 (1997)

ENFORCEMENT POLICY

severity of violations; DD-97-4, 45 NRC 86 (1997)

EXAMINATIONS

reactor operator license, score rounding; LBP-97-2, 45 NRC 51 (1997); LBP-97-6, 45 NRC 130 (1997)

FINAL ENVIRONMENTAL IMPACT STATEMENT

supplementation by licensing board decision and underlying adjudicatory record; LBP-97-3, 45 NRC 99 (1997)

GENERAL LICENSES

authorization for onsite storage of spent nuclear fuel: DD-97-3, 45 NRC 71 (1997)

GENERATORS

See Diesel Generators

GENERIC COMMUNICATIONS

application and regulatory status of; LBP-97-1, 45 NRC 7 (1997)

HEALTH PHYSICS TECHNICIANS

qualification and training; DD-97-7, 45 NRC 258 (1997)

HEARING RIGHTS

on enforcement actions; DD-97-2, 45 NRC 63 (1997)

INSPECTION

See NRC Inspection

INTERVENTION PETITIONS

protective, for preservation of minority owner's interest; LBP-97-4, 45 NRC 125 (1997)

treated as request for hearing on transfer of ownership; LBP-97-4, 45 NRC 125 (1997)

JURISDICTION

employee protection; DD-97-7, 45 NRC 258 (1997)

where motion for reconsideration has been filed; LBP-97-6, 45 NRC 130 (1997)

LICENSEE CHARACTER

management attitudes and credibility; DD-97-6, 45 NRC 144 (1997)

standards for; DD-97-6, 45 NRC 144 (1997)

LICENSEE EVENT REPORTS

"taking"; DD-97-6, 45 NRC 144 (1997)

LICENSEES

applicability of terms and conditions of Certificate of Compliance for dry storage cask to; DD-97-3, 45 NRC 71 (1997)

LICENSES

construction of terms; LBP-97-1, 45 NRC 7 (1997) 


\section{SUBJECT INDEX}

See Also Byproduct Materials License; Reactor Operator License

LICENSING BOARDS

jurisdiction where motion for reconsideration has been filed; LBP-97-6, 45 NRC 130 (1997)

MAINTENANCE

signout procedures to measuring and test equipment, violations of; DD-97-4, 45 NRC 86 (1997)

MATERIAL, FALSE STATEMENT

definition of; DD-97-6, 45 NRC 144 (1997)

MODE CHANGES

with rquired equipment inoperable; DD-97-6, 45 NRC 144 (1997)

MULTIASSEMBLY SEALED BASKET

cooling skid; DD-97-1, 45 NRC 33 (1997)

weld defects in; DD-97-1, 45 NRC 33 (1997)

NOTICE OF VIOLATION

NRC discretion in issuing; DD-97-6, 45 NRC 144 (1997)

NRC INSPECTION

of fabrication facilities for NUHOMS dry storage casks; DD-97-3, 45 NRC 71 (1997)

NUCLEAR REGULATORY COMMISSION

jurisdiction over employee protection; DD-97-7, 45 NRC 258 (1997)

OPERATING LICENSE AMENDMENT PROCEEDINGS

issues for consideration in; LBP-97-1, 45 NRC 7 (1997)

OPERATING LICENSE AMENDMENTS

technical specification changes; LBP-97-1, 45 NRC 7 (1997)

PROOF

See Burden of Proof

RADIATION DOSE

to yisitors of radiation therapy patients denial of byproduct material license amendment to increase; LBP-97-5, 45 NRC 128 (1997)

RADIATION THERAPY

doses to visitors of patients; LBP-97-5, 45 NRC 128 (1997)

RADIOACTIVE WASTE SYSTEMS

alleged operation and intimidation of plant review board members in connection with; DD-97-6, 45 NRC 144 (1997)

REACTOR OPERATOR LICENSE

examination score; LBP-97-6, 45 NRC 130 (1997)

REACTOR OPERATORS

examination score; LBP-97-2, 45 NRC 51 (1997)

RECONSIDERATION

of Commission decision to decline review of an issue; CLI-97-2, 45 NRC 3 (1997)

RECONSIDERATION, MOTION FOR

licensing board jurisdiction; LBP-97-6, 45 NRC 130 (1997)

new arguments or evidence in; LBP-97-6, 45 NRC 130 (1997)

REGULATORY GUIDES

application and regulatory status of; LBP-97-1, 45 NRC 7 (1997)

interpretation of; LBP-97-6, 45 NRC 130 (1997)

RESIDUAL HEAT REMOVAL PUMP

failure to declare inoperability and enter LCO; DD-97-6, 45 NRC 144 (1997)

REVIEW

of licensing board approval of settlement agreement, standard for; CLI-97-1, 45 NRC 1 (1997)

of partial initial decision on enrichment facility licensing; CLI-97-3, 45 NRC 49 (1997)

reconsideration of Commission decision to decline; CLI-97-2, 45 NRC 3 (1997)

RULES OF PRACTICE

amicus curiae, scope of participation; CLI-97-4, 45 NRC 95 (1997)

burden of proof on applicants; LBP-97-3, 45 NRC 99 (1997) 
intervention petition treated as request for hearing on transfer of ownership; LBP-97-4, 45 NRC 125 (1997)

reconsideration motions; CLI-97-2, 45 NRC 3 (1997)

show-cause proceeding, purpose of; DD-97-2, 45 NRC 63 (1997)

standard for institution of show-cause proceedings; DD-97-4, 45 NRC 86 (1997)

SAFEGUARDS

alleged concealment of problems; DD-97-6, 45 NRC 144 (1997)

SAFETY ANALYSIS REPORT

requirement for vendors seeking NRC approval of spent fuel storage casks; DD-97-3, 45 NRC 71 (1997)

SCHEDULE

briefing, for review of partial initial decision on enrichment facility licensing; CLI-97-3, 45 NRC 49 (1997)

briefing, to account for amicus curiae participation; CLI-97-4, 45 NRC 95 (1997)

SENIOR REACTOR OPERATORS

definition of; LBP-97-2, 45 NRC 51 (1997)

SERVICE OF DOCUMENTS

for Commission review of partial initial decision on enrichment facility licensing; CLI-97-3, 45 NRC 49 (1997)

SETTLEMENT AGREEMENTS

challenges to licensing board approval of; CLI-97-1, 45 NRC 1 (1997)

SHOW-CAUSE PROCEEDINGS

appropriate focus of; DD-97-2, 45 NRC 63 (1997)

purpose of; DD-97-2, 45 NRC 63 (1997)

standard for instimtion of; DD-97-4, 45 NRC 86 (1997)

SHUTDOWN

margin, miscalculation of; DD-97-6, 45 NRC 144 (1997)

SPENT FUEL

dry-cask storage on site at nuclear power plants; DD-97-5, 45 NRC 135 (1997)

integrity during cooling; DD-97-1, 45 NRC 33 (1997)

unloading procedures for dry storage casks, violations of requirements for; DD-97-1, 45 NRC 33 (1997)

SPENT FUEL POOL

heavy load handling over; LBP-97-1, 45 NRC 7 (1997)

SPENT FUEL STORAGE

design deficiencies in NUHOMS dry-shielded canisters; DD-97-3, 45 NRC 71 (1997)

SURVEILLANCE

testing of containment isolation valves; DD-97-6, 45 NRC 144 (1997)

TECHNICAL SPECIFICATIONS

changes regarding heavy load handling over spent fuel pool; LBP-97-1, 45 NRC 7 (1997)

construction of the term "except"; LBP-97-1, 45 NRC 7 (1997)

TESTING

surveillance, of containment isolation valves; DD-97-6, 45 NRC 144 (1997)

THERMAL-HYDRAULIC MODELING

cooling process for dry casks; DD-97-1, 45 NRC 33 (1997)

TRANSFER OF LICENSE

illegal; DD-97-6, 45 NRC 144 (1997)

TRANSFER OF OWNERSHIP

dismissal of protective intervention petition and termination of proceeding; LBP-97-4, 45 NRC 125 (1997)

URANIUM TAILS, DEPLETED

disposal, responsibility for; LBP-97-3, 45 NRC 99 (1997)

USEC PRIVATIZATION ACT

depleted uranium tails disposal; LBP-97-3, 45 NRC 99 (1997) 


\section{SUBJECT INDEX}

\section{VALVES}

See Containment Isolation Valves; Dilution Valves

VENDORS

NRC inspection of facilities; DD-97-3, 45 NRC 71 (1997)

VIOLATIONS

noncited; DD-97-4, 45 NRC 86 (1997)

of signout procedures to measuring and test equipment; DD-97-4, 45 NRC 86 (1997)

See Also Notice of Violation

WELDS

defects in multiassembly sealed basket; DD-97-1, 45 NRC 33 (1997) 


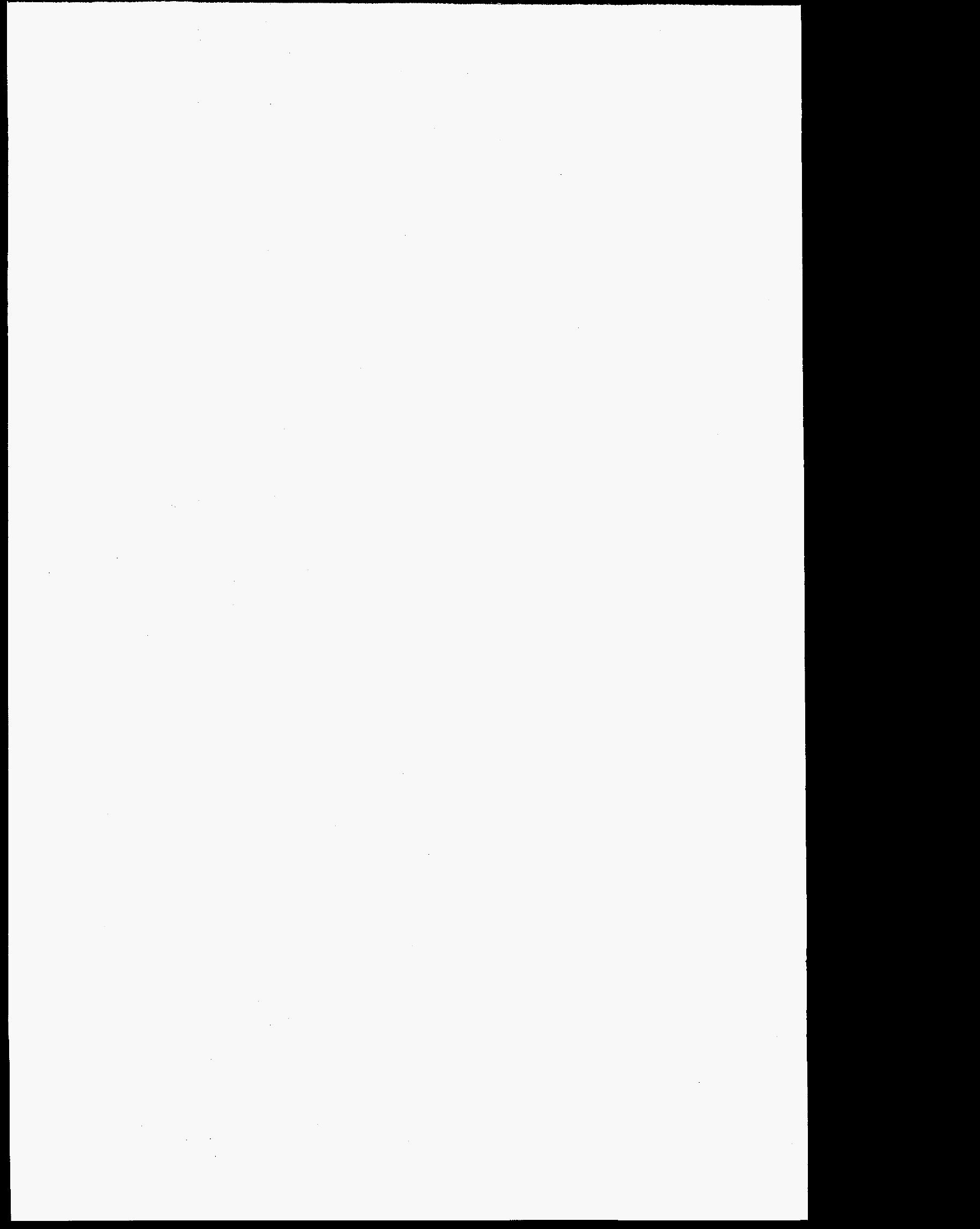




\section{FACILITY INDEX}

ARKANSAS NUCLEAR ONE, Units 1 and 2; Docket Nos. 50-313, 50-368, 72-13

REQUEST FOR ACTION; March 4, 1997; DIRECTOR'S DECISION UNDER 10 C.F.R. \$2.206; DD-97-5, 45 NRC 135 (1997)

CLAIBORNE ENRICHMENT CENTER; Docket No. 70-3070-ML

CONSTRUCTION PERMIT--OPERATING LICENSE PROCEEDING; March 7, 1997; PARTIAL

INITIAL DECISION (Resolving Contentions B and J.3); LBP-97-3, 45 NRC 99 (1997)

MATERIALS LICENSE; January 29, 1997; ORDER; CLI-97-2, 45 NRC 3 (1997)

MATERIALS LICENSE; February 13, 1997; ORDER; CLI-97-3, 45 NRC 49 (1997)

MATERIALS LICENSE; March 21, 1997; ORDER; CLI-97-4, 45 NRC 95 (1997)

CLINTON POWER STATION, Unit 1; Docket No. 50-461-OLA

OPERATING LICENSE AMENDMENT; March 11, 1997; MEMORANDUM AND ORDER

(Terminating Proceeding); LBP-97-4, 45 NRC 125 (1997)

DAVIS-BESSE INDEPENDENT SPENT FUEL STORAGE INSTALLATION; Docket Nos. 50-346, $72-1004$

REQUEST FOR ACTION; February 5, 1997; DIRECTOR'S DECISION UNDER 10 C.F.R. \$2.206; DD-97-3, 45 NRC 71 (1997)

HATCH NUCLEAR PLANT, Units 1 and 2; Docket Nos, 50.424, 50-425

REQUEST FOR ACTION; March 18, 1997; DIRECTOR'S DECISION UNDER 10 C.F.R. \& 2.206; DD-97-6, 45 NRC 144 (1997)

MILLSTONE NUCLEAR POWER STATION, Unit 1; DD-97-4, 45 NRC 86 (1997)

REQUEST FOR ACTION; February 11, 1997; DIRECTOR'S DECISION UNDER 10 C.F.R. $\$ 2.206$; DD-97-4, 45 NRC 86 (1997)

OYSTER CREEK NUCLEAR GENERATING STATION; Docket No. 50-219-OLA

OPERATING LICENSE AMENDMENT; January 31, 1997; MEMORANDUM AND ORDER (Ruling on Summary Disposition Motion); LBP-97-1, 45 NRC 7 (1997)

PALISADES NUCLEAR PLANT; Docket Nos. 50-255, 72-7

REQUEST FOR ACTION; January 23, 1997; DIRECTOR'S DECISION UNDER 10 C.F.R. \$2.206; DD-97-1, 45 NRC 33 (1997)

REQUEST FOR ACTION; March 4, 1997; DIRECTOR'S DECISION UNDER 10 C.F.R. $\$ 2.206$ DD-97-5, 45 NRC 135 (1997)

POINT BEACH NUCLEAR PLANT, Units 1 and 2; Docket Nos. 50-266, 50-301, 72-5

REQUEST FOR ACTION; March 4, 1997; DIRECTOR'S DECISION UNDER 10 C.F.R. § 2.206; DD-97-5, 45 NRC 135 (1997)

VOGTLE ELECTRIC GENERATING PLANT, Units 1 and 2; Docket Nos. 50-321, 50-366

REQUEST FOR ACTION; March 18, 1997; DIRECTOR'S DECISION UNDER 10 C.F.R. § 2.206; DD-97-6, 45 NRC 144 (1997) 


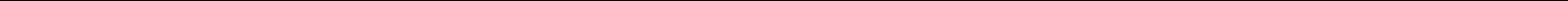

